\title{
Apakah Harga dan Brand Image Berpengaruh Terhadap Keputusan Pembelian?
}

\author{
Nurul Maulida, Siska Maya \\ Pendidikan Ekonomi, Universitas Indraprasta PGRI, Fakultas Ilmu Pendidikan dan Pengetahuan Sosial \\ Jl Nangka No 58 Tanjung Barat \\ may3110@yahoo.com
}

\begin{abstract}
The purpose of this study is to determine the effect of price and brand image on purchasing decisions. The method used in this research is nonprobability sampling. The sampling technique used in this study was accidental sampling, data collection using a questionnaire. Data analysis uses multiple linear regression. The results showed that price influences purchasing decisions and brand image influences purchasing decisions. Simultaneously brand image has a significant effect on purchasing decisions.
\end{abstract}

Keywords- Price; Brand Image; Purchasing Decisions

Abstrak - Tujuan dari penelitian ini yaitu mengetahui pengaruh harga dan brand image terhadap keputusan pembelian. Metode yang digunakan dalamalam penelitian ini adalah nonprobability sampling. Teknik pengambilan sampel yang digunakan dalam penelitian ini adalah accidental sampling, pengumpulan data menggunakan kuesioner. Analisis data menggunakan regresi linier berganda. Hasil penelitian menunjukkan bahwa harga berpengaruh terhadap keputusan pembelian dan brand image berpengaruh terhadap keputusan pembelian. Secara simulta brand image berpengaruh signifikan terhadap keputusan pembelian.

Kata Kunci- Harga; Brand Image; Keputusan Pembelian

\section{PENDAHULUAN}

Perkembangan media teknologi komunikasi di Indonesia semakin berkembang, salah satunya yaitu handphone. Indonesia ialah negara berkembang dengan jumlah penduduk yang semakin banyak, hal itu dapat menarik produsen alat komunikasi untuk bersaing di pasar. Demi meningkatkan daya saing antar perusahaan, salah satu usahanya ialah harus memperhatikan harga agar mampu bersaing dengan produsen alat komunikasi lainnya [1]. Dan menciptakan citra merek yang positif dimata konsumen.

Keputusan pembelian yang dilakukan oleh konsumen seperti melakukan pertimbangan harga produk dan brand image atau citra merek. Konsumen saat memutuskan pembelian pasti memilih produk sesuai dengan kebutuhan agar dapat memuaskan dirinya sesuai keinginan [2]. Hal tersebut dapat menciptakan sebuah keputusan pembelian yang merupakan respon dari konsumen atas barang yang telah ditawarkan oleh perusahaan tersebut guna untuk melakukan pembelian terhadap produk yang dijual oleh penjual.

Berdasarkan penjelasan dari keputusan pembelian, terdapat faktor yang dapat mempengaruhi keputusan pembelian yaitu harga produk dan brand image atau citra merek. Salah satu faktor yang membuat konsumen melakukan memutuskan pembelian adalah harga , menurut [3] harga merupakan salah satu faktor penting dari sisi penyedia jasa untuk memenangkan suatu persaingan dalam memasarkan produknya, oleh karena itu harga harus ditetapkan, hal ini sependapat dengan Ferdinand (2008 : 121) bahwa harga merupakan salah satu variabel penting dalam pemasaran, dimana harga dapat mempengaruhi konsumen dalam mengambil keputusan untuk membeli suatu produk. Berdasarkan hasil penelitian [3] menyatakan harga berpengaruh secara signifikan yaitu secara parsial maupun simultan terhadap keputusan pembelian smartphone Sony Xperia Z series di counter Insight Plaza Marina Surabaya. Sedangkan penelitian [4] menyatakan harga tidak berpengaruh secara signifikan terhadap keputusan pembelian. Penelitian [5] menyatakan harga berpengaruh terhadap keputusan pembelian. Begitu juga penelitian [6] menyatakan harga memiliki pengaruh positif terhadap keputusan pembelian handphone Samsung yang ada di Samsung Mobile IT Center Manado. Dan peneliti [7] menyatakan harga mempengaruhi keputusan pembelian handphone Xiaomi di Kota Langsa sebesar 30,4\%, sedangkan sisanya $69,6 \%$ dipengaruhi oleh variabel lain di luar model penelitian ini.

Berdasarkan pendapat para peneliti, dapat disimpulkan bahwa sebagian konsumen tidak mempertimbangkan harga sebagai keputusan 
pembelian, meskipun harga yang tinggi atau rendah tetapi tidak sesuai dengan kualitas produk yang didapat, konsumen tentu akan merasa kecewa. Mungkin konsumen dari kalangan kelas bawah yang lebih mempertimbangkan harga. Untuk masyarakat kalangan kelas menengah apalagi kalangan kelas atas, harga bukanlah masalah. Bagi mereka yang terpenting adalah produk yang sesuai dengan keinginan mereka atau produk keluaran terbaru yang sedang menjadi trend.

Selain harga, brand image atau citra merek juga menjadi salah satu faktor yang mempengaruhi dalam keputusan pembelian. Menurut (Durianto dan Budiman, 2004) dalam penelitian [4] menyatakan brand atau merek adalah nama, istilah, tanda, simbol desain ataupun kombinasinya yang mengidentifikasi suatu produk atau jasa yang dihasilkan oleh suatu perusahaan. Menurut Penelitian sebelumnya [4] menyatakan bahwa citra merek tidak berpengaruh secara signifikan terhadap keputusan pembelian. Sedangkan penelitian yang dilakukan oleh [8] menyatakan bahwa citra merek berpengaruh terhadap keputusan pembelian Handphone BlackBerry Gemini. Begitu juga dengan penelitian yang dilakukan [9] menyatakan citra merek berpengaruh positif terhadap keputusan pembelian. Penelitian yang dilakukan oleh [10] juga menyatakan citra merek memberikan pengaruh terhadap keputusan pembelian. Dan penelitian [11] menyatakan secara parsial citra merek tidak berpengaruh terhadap keputusan pembelian secara simultan citra merek berpengaruh positif dan signifikan terhadap keputusan pembelian.

Berdasarkan pendapat para peneliti dapat disimpulkan citra merek adalah merek dapat memberikan banyak keuntungan bagi perusahaan dan menjadikan pembeda diantara pesaing jika dikelola dan dikembangkan dengan benar.

Alasan peneliti melakukan pengamatan produk Samsung, karena produk samsung yang sudah di ketahui oleh masyarakat dan dilihat dari sisi harga yang sesuai dengan kualitas handphone tersebut. Berdasarkan pengamatan peneliti terjadi masalah pada penurunan tingkat penjualan pada periode tertentu.

Pada kuartal II-2019 Oppo memiliki pangsa pasar 26\% dengan pertumbuhan secara tahunan 54\%. Sementara Samsung memiliki pangsa pasar 24\% atau hampa tumbuh $10 \%$. Peringkat ketiga dipegang oleh Xiaomi yang memiliki pangsa pasar $15 \%$ karena penjualan tumbuh negatif 9\%. Adapun Vivo dan Realme menguasai $15 \%$ dan $7 \%$ pasar ponsel
Indonesia, seperti dikutip dari detikINET, $(13 / 8 / 2019)$.

Penurunan penjualan handphone merek samsung pada periode tertentu diperkirakan karena banyaknya jenis produk yang membuat konsumen bingung untuk memutuskan pembelian dan banyaknya persaingan di produk handphone merek lain yang muncul dengan harga yang sangat terjangkau. Sebab untuk memahami perilaku konsumen memang tidak mudah, banyaknya faktor yang dipertimbangkan.

Tujuan penelitian untuk mendeskripsikan pengaruh harga dan Brand Image terhadap keputusan pembelian. Dengan demikian, manfaat penelitian secara teoritis yaitu dapat menambah wawasan keilmuan serta secara praktis memberikan masukan guna untuk pihak perusahaan dalam mengoptimalkan produk.

Berdasarkan latar belakang masalah yang telah dikemukakan diatas dapat dirumuskan masalah sebagai berikut :

1. Bagaimana pengaruh harga secara parsial terhadap keputusan pembelian handphone?

2. Bagaimana pengaruh brand image secara parsial terhadap keputusan pembelian handphone?

3. Bagaimana pengaruh harga produk dan brand image secara srimultan terhadap keputusan pembelian handphone?

Sesuai dengan latar belakang dan perumusan masalah yang ditentukan maka tujuan penelitian yang hendak dicapai adalah:

1. Untuk mengetahui pengaruh harga produk terhadap keputusan pembelian handphone.

2. Untuk mengetahui pengaruh brand image terhadap keputusan pembelian handphone.

3. Untuk mengetahui pengaruh harga produk dan brand image terhadap keputusan pembelian handphone.

\section{Keputusan Pembelian}

\section{KAJIAN PUSTAKA}

Pada umumnya keputusan pembelian yang dilakukan oleh konsumen adalah membeli merek yang paling disukai dan dengan design yang sedang trend dan dengan harga terjangkau. Keputusan pembelian merupakan sikap seseorang untuk membeli atau menggunakan suatu produk baik berupa barang atau jasa yang telah di percayai dapat memuaskan dirinya.

Pendapat Nugroho (2002: 2) yang dikutip oleh Nurdin, Djuhartono (2019) menyatakan bahwa keputusan membeli merupakan proses aktivitas 
masing-masing individu yang dilakukan dalam rangka evaluasi, mendapatkan, penggunaan atau mengatur barang dan jasa. Menurut pendapat Kotler (1987: 98), menyatakan bahwa keputusan membeli terjadi karena melalui proses prilaku yang meliputi empat tahap, yaitu : (1) Pengenalan kebutuhan, artinya proses pembelian diawali dengan adanya kebutuhan yang dirasakan konsumen. (2) Pencairan informasi artinya setelah konsumen merasakan adanya kebutuhan sesuatu barang atau jasa. Selanjutnya konsumen mencari informasi baik yang disimpan dalam ingatan (information internal), maupun informasi yang didapat dari lingkungan (eksternal). (3) Evaluasi informasi artinya konsumen mengevaluasi alternatif pilihan dalam memenuhi kebutuhannya, dan (4) Kepuasan membeli artinya konsumen yang telah melakukan pilihan terhadap berbagai alternatif, biasanya konsumen membeli produk yang paling disukai.

\section{Faktor - Faktor yang Mempengaruhi Keputusan Pembelian}

Menurut Kotler dan Armstrong (2008) yang terdapat pada jurnal peneliti [7] menyatakan ada empat faktor yang mempengaruhi perilaku konsumen dalam memutuskan melakukan pembelian, yaitu : (1) Faktor Budaya, Faktor budaya mempunyai pengaruh yang luas dan mendalam terhadap perilaku, mencakup budaya (kultur, sub budaya, dan kelas sosial). Budaya adalah susunan nilai-nilai dasar, persepsi, keinginan, dan perilaku yang dipelajari anggota suatu masyarakat dari keluarga dan institusi penting lainnya. (2) Faktor Sosial. Selain faktor budaya, perilaku konsumen juga dipengaruhi oleh faktor-faktor sosial seperti kelompok acuan, keluarga, serta peran dan status. (3) Faktor Pribadi, Keputusan seorang pembeli juga dipengaruhi oleh karakteristik pribadi seperti umur pembeli dan tahap siklus hidup, pekerjaan, keadaan ekonomi, gaya hidup dan kepribadian. (4) Faktor Psikologis yaitu Motivasi dan Persepsi.

Tahapan Untuk Melakukan Keputusan Pembelian Menurut Kotler dan Keller (2012:193) menyatakan terdapat enam tahap keputusan pembelian dilakukan oleh konsumen pelanggan yaitu: 1) Pemilihan Produk, konsumen mengambil keputusan untuk membeli sebuah produk atau menggunakan uangnya untuk tujuan yang lain. Dalam hal ini perusahaan harus memusatkan perhatiannya kepada orang-orang yang berminat membeli produknya. 2) Pemilihan Merek, konsumen harus mengambil keputusan tentang merek mana yang akan dibeli. Setiap merek mempunyai perbedaan tersendiri.
Dalam hal ini perusahaan harus mengetahui bagaimana konsumen memilih sebuah merek. 3) Pemilihan Saluran Pembelian, konsumen harus mengambil keputusan tentang penyalur mana yang akan dikunjungi. Setiap konsumen berbeda-beda dalam hal menentukan penyalur biasanya dikarenakan lokasi yang dekat, harga yang murah, persediaan barang yang lengkap, kenyamanan belanja, keluasan tempat dan sebagainya. 4) Jumlah Pembelian, konsumen dapat mengambil keputusan seberapa banyak produk yang akan dibelinya. Dalam hal ini perusahaan harus mempersiapkan banyaknya produk sesuai dengan kebutuhan konsumen. 5) Waktu Pembelian, keputusan konsumen dalam waktu pembelian yang berbeda beda, misalnya: ada yang membeli setiap hari, seminggu sekali, dua minggu sekali, bahkan satu bulan sekali tergantung kebutuhannya.

\section{Harga}

Menurut Saladin (2007) pada [7] menyatakan bahwa harga adalah jumlah moneter yang dibebankan oleh suatu unit usaha kepada pembeli atau pelanggan atas barang atau jasa yang dijual atau diserahkan. Sedangkan Menurut Alma (2007), pada prinsipnya harga jual harus dapat menutupi biaya penuh ditambah dengan laba yang wajar. Tjiptono (2008) menyatakan bahwa harga adalah sejumlah uang dan jasa atau barang-barang yang tersedia ditukarkan oleh pembeli untuk mendapatkan berbagai pilihan produk produk dan jasa-jasa yang disediakan penjual.

$$
\text { Sedangkan menurut Alma (2007) }
$$

memberikan penjelasan bahwa perusahaan harus mempertimbangkan banyak faktor dalam menetapkan kebijaksanaan harga, yaitu: 1) Memilih tujuan penetapan harga. 2) Menentukan permintaan. 3) Memperkirakan biaya. 4) Menganalisis harga dan penawaran pesaing. 5) Memilih metoe penetapan harga. 6) Memilih harga akhir.

\section{Tujuan Penetapan Harga}

Menurut Kotler (2009) pada kutipan [7], perusahaan dapat mengejar salah satu dari lima tujuan utama melalui penetapan harga, yaitu: (1) Survival (bertahan hidup) Tujuan ini dipilih oleh perusahaan jika perusahaan mengalami kelebihan kapasitas, persaingan yang ketat, atau keinginan konsumen yang berubahubah. Karena itu perusahaan akan menetapkan harga jual yang rendah dengan harapan pasar akan peka terhadap harga. (2) Maximum Current Profit (laba sekarang maksimum) Perusahaan memilih tujuan ini akan memperkirakan permintaan dan biaya yang berkaitan dengan berbagai alternatif 
harga dan memilih harga yang akan menghasilkan laba sekarang, arus kas, atau tingkat pengembalian investasi yang maksimum. (3) Maximum Market Share (pangsa pasar maksimum) Perusahaan yang memilih tujuan ini yakin bahwa volume penjualan yang lebih tinggi akan menghasilkan biaya per-unit yang lebih rendah dan laba jangka panjang yang lebih tinggi. Perusahaan menetapkan harga terendah dengan asumsi bahwa pasar sangat peka terhadap perubahan harga, sehingga harga rendah tersebut dapat merangsang pertumbuhan pasar, itu disebut harga penetrasi-pasar (market penetration pricing). (4) Maximum Market Skimming (menyaring pasar secara maksimum) Dalam tujuan ini perusahaan menetapkan harga tertinggi bagi setiap produk baru yang dikeluarkan, dimana kemudian secara berangsur-angsur perusahaan menurunkan harga untuk menarik segmen lain yang peka terhadap harga. Tujuan ini dapat diterapkan dengan adanya kondisikondisi atau asumsi-asumsi sebagai berikut: a) Sejumlah pembeli yang memadai memiliki permintaan sekarang yang tinggi. b) Biaya per unit untuk memproduksi volume kecil tidak terlalu tinggi. c) Harga awal yang tinggi tidak menarik lebih banyak pesaing kepasar. d) Harga yang tinggi menyatakan citra produk yang unggul. (5) Product-Quality Leadership (kepemimpinan mutu-produk) Tujuan ini dipilih oleh perusahaan jika perusahaan ingin menjadi pemimpin pasar dalam hal kualitas produk, dan harga yang ditetapkan menjadi relatif tinggi untuk men utupi biaya-biaya penelitian dan pengembangan serta biaya untuk menghasilkan mutu produk yang tinggi.

\section{Indikator Harga}

Pendapat Kotler (2009) yang terdapat pada jurnal [7] , indikator- indikator harga yaitu sebagai berikut: (1) Keterjangkauan harga, Harga yang terjangkau adalah harapan konsumen sebelum mereka melakukan pembelian. Konsumen akan mencari produk-produk yang harganya dapat mereka jangkau. (2) Kesesuaian harga dengan kualitas produk, Untuk produk tertentu biasanya konsumen tidak keberatan apabila harus membeli dengan harga relatif mahal asalkan kualitas produknya baik.Namun konsumen lebih menginginkan produk dengan harga murah dan kualitasnya baik. (3) Daya saing harga, Perusahaan menetapkan harga jual suatu produk dengan mempertimbangkan harga produk yang dijual oleh pesaingya agar produknya dapat bersaing di pasar. (4) Kesesuaian harga dengan manfaat, Konsumen terkadang mengabaikan harga suatu produk namun lebih mementingkan manfaat dari produk tersebut.

\section{Citra Merek}

Citra merek ialah suatu hal yang tentu sudah ada dalam benak konsumen baik dinilai secara positif maupun negatif sebelum menentukan keputusan pembelian. [7] mengutip menurut Tjiptono (2008), yang dimaksud dengan citra merek (brand image) adalah deskripsi tentang asosiasi dan keyakinan konsumen terhadap merek tertentu. Menurut Kotler dan Keller (2009), citra merek adalah proses dimana seseorang memilih, mengorganisasikan, dan mengartikan masukan informasi untuk menciptakan suatu gambaran yang berarti. Kertajaya (2007) mengemukakan pendapatnya bahwa yang dimaksud dengan citra merek adalah gebyar dari seluruh asosiasi yang terkait pada suatu merek yang sudah ada di benak konsumen. Menurut Ratri (2007), citra merek merupakan asosiasi dari semua informasi yang tersedia mengenai produk, jasa dan perusahaan dari merek yang dimaksud. Informasi ini didapat dari dua cara, yang pertama melalui pengalaman konsumen secara langsung, yang terdiri dari kepuasan fungsional dan kepuasan emosional. Merek tersebut tidak cuma dapat bekerja maksimal dan memberikan performansi yang dijanjikan tapi juga harus dapat memahami kebutuhan konsumen, mengusung nilai-nilai yang diinginkan oleh konsumen dan juga memenuhi kebutuhan individual konsumen yang akan memberi kontribusi atas hubungan dengan merek tersebut. Kedua, persepsi yang dibentuk oleh perusahaan dari merek tersebut melalui berbagai macam bentuk komunikasi, seperti iklan, promosi, hubungan masyarakat (public relations), logo, dan lain sebagainya (Ratri, 2007).

\section{Indikator Citra Merek}

Adapun indikator citra merek menurut Ratri (2007) yang dapat menjadi pertimbangan dalam memutuskan pembelian yaitu sebagai berikut: (1) Atribut produk, merupakan hal-hal yang berkaitan dengan merek tersebut sendiri, seperti kemasan, rasa, harga, dan lain- lain. (2) Keuntungan konsumen , merupakan kegunaan produk dari merek tersebut. (3) Kepribadian merek , merupakan asosiasi yang mengenai kepribadian sebuah merek apabila merek tersebut adalah manusia.

\section{Faktor yang Mempengaruhi Citra Merek}

Tidak hanya indikator citra merek saja yang dapat membuat konsumen untuk terdorong membeli produk. Menurut Kertajaya (2007) yang dikutip oleh [7] menyatakan, ada faktor-faktor yang mempengaruhi citra merek yaitu sebagai berikut: (1) Kualitas atau mutu, berkaitan dengan kualitas produk yang ditawarkan oleh produsen dengan merek 
tertentu. (2) Dapat dipercaya atau diandalkan, berkaitan dengan pendapat dan kesepakatan yang di bentuk oleh masyarakat tentang suatui produk yang dikonsumsi. (3) Kegunaan atau manfaat, yang terkait dengan fungsi dari suatu produk yang bisa dimanfaatkan oleh konsumen. (4) Pelayanan, yang berkaitan dangan tugas produsen dalam melayani konsumennya. (5) Resiko berkaitan dengan untung rugi yang dialami oleh konsumen. (6) Harga, dalam hal ini yang dikeluarkan konsumen untuk mempengaruhi suatu produk, juga dapat mempengaruhi citra berkaitan dengan tinggi rendahnya atau banyak sedikitnya jumlah uang jangka panjang. (7) Image, yang dimiliki merek itu sendiri, yaitu berupa pelanggan, kesempatan dan informasi yang berkaitan dengan suatu merek dari produk tertentu.

\section{METODE PENELITIAN}

Penelitian ini merupakan penelitian kuantitatif. Objek penelitian pada SES Ciputra Mall. Populasi penelitian yaitu konsumen pembeli samsung, populasi ini tak terhingga jumlahnya sehingga diperlukan tindakan dalam pengambilan sampel dalam penelitian ini dan formula dasar dalam menentukan ukuran sampel untuk populasi yang tidak teridentifikasikan secara pasti jumlahnya, sampel ditentukan secara langsung sebesar 100. Jumlah sampel dalam penelitian ini adalah 100 responden yang cukup mewakili untuk di teliti, penentuan sampel menggunakan teori (Donald R. Cooper, 1996) dengan teknik accidental sampling. Sedangkan teknik pengumpulan data dalam penelitian ini melalui kuesioner. Peneliti menyebarkan kuesioner kepada 100 responden di objek penelitian. Teknik analisis data yang digunakan yaitu analisis regresi linier berganda.

Metode pengumpulan data yang digunakan dalam penelitian ini menggunakan sumber data primer. Untuk memperoleh data informasi diperlukan dalam penelitian ini digunakan metode pengumpulan data pada penelitian ini dilakukan dengan cara studi pustaka dilakukan dengan menghimpun informasi yang relevan diperoleh dari laporan penelitian, karangan-karangan ilmiah, dan sumber tertulis baik cetak maupun elektronik. Dan Kuesioner adalah metode pengumpulan data dengan cara mengajukan atau membuat daftar pertanyaan yang berkaitan dengan citra merek, fitur dan harga produk handphone samsung terhadap keputusan pembelian yang diajukan kepada para pembeli dan pengguna handphone merek Samsung di SES Ciputra Mall.
Dalam kuesioner ini dibuat skala 1-5 untuk mendapatkan data yang bersifat interval dan diberi skor atau nilai dengan kategori pengukuran : Sangat Tidak Setuju (STS) dengan bobot 1, Tidak Setuju (TS) dengan bobot 2, Kurang Setuju (KS) dengan bobot 3, Setuju (S) dengan bobot 4, Sangat Setuju (SS) dengan bobot 5 .

Teknik analisis data pada penelitian ini adalah Analisis Regresi linear Berganda, Uji Hipotesis yaitu Uji f dan Uji t, Koefisien Korelasi, dan Koefisien Determinasi.

\section{HASIL DAN PEMBAHASAN}

Hasil Uji Regresi Linier Berganda

Tabel 1. Hasil Uji Regresi

Coefficients $^{\mathrm{a}}$

\begin{tabular}{lrrrrr}
\hline Model & $\begin{array}{c}\text { Unstandar } \\
\text { dized }\end{array}$ & $\begin{array}{c}\text { Standar } \\
\text { dized }\end{array}$ & $\begin{array}{c}\text { Std. } \\
\text { Error }\end{array}$ & T Beta & Sig. \\
\hline $\begin{array}{l}\text { (Constan } \\
\text { t) }\end{array}$ & 11.468 & 1.95 & & 5.88 & 0 \\
$\begin{array}{l}\text { Harga } \\
(\mathrm{x} 1)\end{array}$ & 0.257 & 0.086 & 0.3 & 2.996 & 0.003 \\
$\begin{array}{l}\text { Brand } \\
\text { Image } \\
(\mathrm{x} 2)\end{array}$ & 0.25 & 0.084 & 0.297 & 2.97 & 0.004 \\
\hline
\end{tabular}

a.Depedent Variable: Keputusan Pembelian (Y)

Sumber : Hasil Pengolahan SPS Versi 24.0

Pada tabel 1 ditemukan bahwa seluruh variabel independen memiliki pengaruh terhadap variabel dependen. Pada penelitian ini ditemukan pula bahwa harga memiliki pengaruh yang lebih besar dibandingkan brand image dalam keputusan pembelian. Hasil tersebut kemudian dapat dimasukan kedalam persamaan analisis regresi berganda seperti dibawah ini :

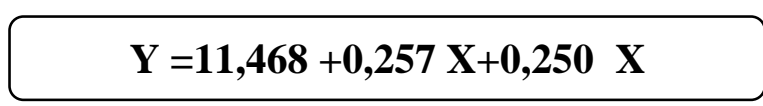

Tabel 2. Hasil Uji t

Coefficients $^{\mathrm{a}}$

\begin{tabular}{lrrrrr}
\hline Model & $\begin{array}{c}\text { Unstandar } \\
\text { dized }\end{array}$ & $\begin{array}{c}\text { Standar } \\
\text { dized }\end{array}$ & $\begin{array}{c}\text { Std. } \\
\text { Error }\end{array}$ & T Beta & Sig. \\
\hline $\begin{array}{l}\text { (Constan } \\
\text { t) }\end{array}$ & 11.468 & 1.95 & & 5.88 & 0 \\
$\begin{array}{l}\text { Harga } \\
\text { (x1) }\end{array}$ & 0.257 & 0.086 & 0.3 & 2.996 & 0.003 \\
$\begin{array}{l}\text { Brand } \\
\text { Image } \\
(\mathrm{x} 2)\end{array}$ & 0.25 & 0.084 & 0.297 & 2.97 & 0.004 \\
\hline $\begin{array}{l}\text { a.Depedent Variable: Keputusan Pembelian (Y) } \\
\text { Sumber : Hasil Pengolahan SPS Versi 24.0 }\end{array}$ & & \\
\hline
\end{tabular}


Berdasarkan tabel 2 disimpulkan bahwa kesemua variabel atau dimensi Harga dan Brand Image memiliki pengaruh secara parsial terhadap Keputusan Pembelian handphone merek Samsung. Berikut ini akan dijelaskan hasil pengujian masing-masing variabel secara parsial :

1. Variabel Harga

Hasil pengujian yang diperoleh oleh nilai t untuk variabel harga menunjukkan nilai $\mathrm{t}=$ dengan nilai signifikan sebesar $0,003<0,05$. Dengan nilai signifikan dibawah 0,05 tersebut menunjukkan bahwa Harga berpengaruh positif terhadap Keputusan Pembelian.

Dan $\mathrm{t}_{\text {table }}=\mathrm{t}(\mathrm{a} / 2 ; \mathrm{n}-\mathrm{k}-1=\mathrm{t}(0,05 / 2 ; 100-2-1)=$ $(0,025 ; 97)=1,98472$. Berarti $t_{\text {hitung }}>t_{\text {table }}(2,996$ $>1,98472$ ), maka $\mathrm{H}_{0}$ ditolak dan $\mathrm{H}_{1}$ diterima. Sehingga hipotesis yang berbunyi, secara parsial terdapat pengaruh signifikan antara harga terhadap keputusan pembelian handphone merek Samsung pada SES Ciputra diterima. Variabel harga merupakan variabel yang mempunyai pengaruh postif terhadap keputusan pembelian, hal ini terbukti dengan nilai $t_{\text {hitung }}$ untuk variabel harga merupakan nilai $t_{\text {hitung }}$ yang terbesar dibandingkan dengan nilai $t$ hitung untuk variabel bebas lain.

\section{Variabel Brand Image}

Hasil pengujian yang diperoleh oleh nilai $t$ untuk variabel brand image menunjukkan nilai $\mathrm{t}=$ dengan nilai signifikan sebesar $0,004<0,05$

Dengan nilai signifikan dibawah 0,05 tersebut menunjukkan bahwa brand image berpengaruh positif terhadap Keputusan Pembelian.

Dan $\mathrm{t}_{\text {table }}=\mathrm{t}(\mathrm{a} / 2 ; \mathrm{n}-\mathrm{k}-1=\mathrm{t}(0,05 / 2 ; 100-2-1)=$ $(0,025 ; 97)=1,98472$. Berarti $t_{\text {hitung }}>t_{\text {table }}(2,970>$ 1,98472), maka $\mathrm{H}_{0}$ ditolak dan $\mathrm{H}_{2}$ diterima. Sehingga hipotesis yang berbunyi, secara parsial terdapat pengaruh signifikan antara brand image terhadap keputusan pembelian handphone merek Samsung pada SES Ciputra diterima.

\section{Tabel 3. Hasil Uji F}

ANOVA $^{\mathrm{a}}$

\begin{tabular}{|c|c|c|c|c|c|c|}
\hline & Model & $\begin{array}{l}\text { Sum of } \\
\text { Squares }\end{array}$ & df & $\begin{array}{l}\text { Mean } \\
\text { Square }\end{array}$ & $\mathrm{F}$ & Sig. \\
\hline \multirow{3}{*}{1} & Regression & 73.058 & 2 & 36.529 & 17.637 & $.000^{\mathrm{b}}$ \\
\hline & Residual & 200.902 & 97 & 2.071 & & \\
\hline & Total & 273.96 & 99 & & & \\
\hline
\end{tabular}

a. Dependent Variable: Keputusan Pembelian (Y)

b. Predictors: (Constant), Brand Image (x2), Harga (x1)

Sumber : Hasil Pengolahan SPS Versi 24.0
Berdasarkan hasil pengujian tabel diatas dapat dilihat pada $F_{\text {hitung }}$ sebesar 17,637 dengan nilai $F_{\text {tabel }}$ adalah 3,09 sehingga nilai $F_{\text {hitung }}>F_{\text {tabel }}$ atau 17,637 $>3,09$ dan tingkat signifikan $0,000<0,05$ maka $\mathrm{H}_{0}$ ditolak dan $\mathrm{H}_{3}$ diterima, dapat disimpulkan bahwa variabel harga $\left(\mathrm{x}_{1}\right)$ dan brand image $\left(\mathrm{x}_{2}\right)$ secara bersamaan berpengaruh signifikan terhadap keputusan pembelian handphone merek Samsung pada SES Ciputra.

Tabel 4. Hasil Koefisien Korelasi

Model Summary

\begin{tabular}{cc|c|c|c|c|c|c|c|c}
\hline & $\mathrm{R}$ & $\begin{array}{c}\mathrm{R} \\
\text { Square }\end{array}$ & $\begin{array}{c}\text { Adjusted } \\
\mathrm{R} \\
\text { Square }\end{array}$ & $\begin{array}{c}\text { Std. } \\
\text { Error of } \\
\text { the } \\
\text { Estimate }\end{array}$ & $\begin{array}{c}\mathrm{R} \\
\text { Chare } \\
\text { Change }\end{array}$ & $\begin{array}{c}\mathrm{F} \\
\text { Change }\end{array}$ & $\mathrm{df1}$ & df2 & $\begin{array}{c}\text { Sig. F } \\
\text { Change }\end{array}$ \\
\hline 1 & $.516^{\mathrm{a}}$ & 0.267 & 0.252 & 1.439 & 0.267 & 17.637 & 2 & 97 & 0 \\
\hline
\end{tabular}

a. Predictors: (Constant), brand image (x2), harga (x1)

Sumber : Hasil Pengolahan SPS Versi 24.0

Berdasarkan tabel 4 hasil uji koefisien korelasi , karena nilai $\mathrm{R}$ pengaruh harga dan brand image terhadap keputusan pembelian ini dapat dilihat bahwa hasil Sig $f$ change $0,000<0,05$ maka dapat dikatakan bahwa variabel $\mathrm{X}_{1}$ dan $\mathrm{X}_{2}$ secara srimultan terdapat korelasi atau hubungan terhadap variabel $\mathrm{Y}$. Dan tingkat keeratan hubungan tersebut adalah sebesar $0,516 \mathrm{R}_{\text {hitung }}$ artinya derajat hubungan antara variabel $\mathrm{X}_{1}$ dan $\mathrm{X}_{2}$ terhadap Ydikatagorikan kedalam korelasi sedang.

Tabel 5. Hasil Uji Koefisien Determinasi Model Summary

\begin{tabular}{cc|c|c|c}
\hline Model & $\mathrm{R}$ & R Square & $\begin{array}{c}\text { Adjusted R } \\
\text { Square }\end{array}$ & $\begin{array}{c}\text { Std. Error of } \\
\text { the Estimate }\end{array}$ \\
\hline 1 & $.516^{\mathrm{a}}$ & 0.267 & 0.252 & 1.439 \\
\hline
\end{tabular}

a. Predictors: (Constant), Brand Image (x2), Harga (x1)

Sumber : Hasil Pengolahan SPS Versi 24.0

Dari tabel koefisien determinasi $\left(\mathrm{R}^{2}\right)$ menunjukkan besarnya Adjusted $R^{2}$ Adalah 0,252, hal ini menunjukan bahwa kemampuan variabel harga dan brand image dalam menjelaskan variabel keputusan pembelian adalah sebesar 0,252 atau 25,2\%, Sedangkan sisanya sebesar 74,8 \% ( 100\% - 25,2\%) dijelaskan oleh variabel lain yang tidak dibahas dalam penelitian ini.

\section{KESIMPULAN DAN SARAN}

Berdasarkan pembahasan secara teoritis maupun empiris dari data hasil penelitian tentang pengaruh harga dan brand image terhadap keputusan pembelian handphone merek Samsung pada SES Ciputra, 
peneliti membuat simpulan bahwa hasil penelitian menunjukkan pada hasil pengujian nilai $t$ untuk variabel harga menunjukkan nilai signifikan sebesar $0,003<0,05$. Dengan nilai signifikan dibawah 0,05 tersebut dapat disimpulkan bahwa harga berpengaruh positif terhadap keputusan Pembelian. Dan $\mathrm{t}_{\text {table }}=\mathrm{t}$ $(\mathrm{a} / 2 ; \mathrm{n}-\mathrm{k}-1=\mathrm{t} \quad(0,05 / 2 ; 100-2-1)=(0,025 ; 97)=$ 1,98472 . Berarti $t_{\text {hitung }}>t_{\text {table }}(2,996>1,98472)$, maka $\mathrm{H}_{0}$ ditolak dan $\mathrm{H}_{1}$ diterima. Sehingga hipotesis yang berbunyi, secara parsial terdapat pengaruh signifikan antara harga terhadap keputusan pembelian handphone merek Samsung pada SES Ciputra diterima. Dan pengujian yang diperoleh oleh nilai $t$ untuk variabel brand image menunjukkan nilai $\mathrm{t}=$ dengan nilai signifikan sebesar 0,004 $<0,05$ Dengan nilai signifikan dibawah 0,05 tersebut menunjukkan bahwa brand image berpengaruh positif terhadap keputusan pembelian. Dan $\mathrm{t}_{\text {table }}=\mathrm{t}(\mathrm{a} / 2 ; \mathrm{n}-\mathrm{k}-1=\mathrm{t}$ $(0,05 / 2 ; 100-2-1)=(0,025 ; 97)=1,98472$. Berarti $\mathrm{t}_{\text {hitung }}>\mathrm{t}_{\text {table }}(2,970>1,98472)$, maka $\mathrm{H}_{0}$ ditolak dan $\mathrm{H}_{2}$ diterima. Sehingga hipotesis yang berbunyi , secara parsial terdapat pengaruh signifikan antara brand image terhadap keputusan pembelian handphone merek Samsung pada SES Ciputra.

Pengujian pada tabel uji $\mathrm{f}$ dapat dilihat pada $F_{\text {hitung }}$ sebesar 17,637 dengan nilai $F_{\text {tabel }}$ adalah 3,09 sehingga nilai $\mathrm{F}_{\text {hitung }}>\mathrm{F}_{\text {tabel }}$ atau 17,637 $>3,09$ dan tingkat signifikan $0,000<0,05$ maka $\mathrm{H}_{0}$ ditolak dan $\mathrm{H}_{3}$ diterima, dapat disimpulkan bahwa variabel harga $\left(\mathrm{x}_{1}\right)$ dan brand image $\left(\mathrm{x}_{2}\right)$ secara bersamaan berpengaruh signifikan terhadap keputusan pembelian pada SES Ciputra.

Dari analisis koefisien determinasi menunjukkan besarnya Adjusted $R^{2}$ adalah 0,252, hal ini menunjukkan bahwa kemampuan variabel harga dan brand image dalam menjelaskan variabel keputusan pembelian adalah sebesar 0,252 atau $25,2 \%$. Sedangkan sisanya sebesar $74,8 \% \quad(100-25,2 \%)$ dijelaskan oleh variabel lain yang tidak dibahas dalam penelitian ini.

Berdasarkan hasil penelitian yang telah dilakukan maka peneliti mengajukan beberapa saran sebagai berikut :

1. Harga dari handphone Samsung sudah sesuai dengan persaingan harga merek lain. Perusahaan harus mampu mempertahankan jika perlu berani bersaing harga dengan produk lain.

2. Brand Image atau citra merek handphone Samsung sudah memenuhi criteria pasar. Perusahaan harus mampu mempertahankan prestasi tersebut jika ingin tetap bertahan dipasar.

\section{REFERENSI}

[1] S. Sudiarti, "Sistem Informasi Pemasaran Berbasis Website dalam Meningkatkan Pembelian Kerajinan Anyaman di $\mathrm{Cv}$ Binangkit Kabupaten Tasikmalaya," Bus. Innov. Entrep. J., vol. 1, no. 3, pp. 130-140, 2019, doi: 10.35899/biej.v1i3.66.

[2] N. A. Hamdani and G. A. F. Maulani, "The influence of E-WOM on purchase intentions in local culinary business sector," Int. J. Eng. Technol., vol. 7, no. 2.29, p. 246, 2018, doi: 10.14419/ijet.v7i2.29.13325.

[3] E. V. A. Cahya, "Keputusan Pembelian Smartphone Sony Xperia Z Series Di Counter Insight Plaza Marina Surabaya," pp. 1-15, 2015.

[4] S. Nurhayati, "Pengaruh citra merek, harga dan promosi terhadap keputusan pembelian handphone samsung di yogyakarta," JBMA Vol. IV, No. 2, Sept. 2017 ISSN 2252-5483, vol. IV, no. 2, pp. 60-69, 2017.

[5] S. C. Lotulung, J. Lapian, and S. Moniharapon, "Pengaruh Kualitas Produk, Harga , Dan Wom ( Word of Mouth ) Terhadap Keputusan Pembelian Handphone Evercoss Pada Cv.Tristar Jaya Globalindo Manado," J. EMBA, vol. 3, no. 3, pp. 817826, 2015.

[6] M. L. Mokoagouw, "Pengaruh Gaya Hidup, Harga, Kualitas Produk Terhadap Keputusan Pembelian Handphone Samsung Di Samsung Mobile It Center Manado," J. Berk. Ilm. Efisiensi, vol. 16, no. 01, pp. 493-502, 2016.

[7] S. Amalia and M. O. Asmara, "Pengaruh Citra Merek, Harga, dan Kualitas Produk terhadap Keputusan Pembelian Handphone Merek Xiaomi di Kota Langsa," J. Manaj. dan Keuang., vol. 6, no. 1, p. 666, 2017.

[8] U. Setiawan, P. D. P, and A. T. Haryono, "Pengaruh Citra Merek, Harga, Kualitas Produk dan Gaya Hidup Terhadap Keputusan Pembelian Handphone Blackberry Gemini (Studi pada Mahasiswa Mahasiswi Fakultas Ekonomi Universitas Pandanaran Semarang)," J. Manaj. Pemasar., pp. 1-18, 2015.

[9] Hutami and P. Sari, "PENGARUH CITRA 
MEREK, FITUR, DAN PERSEPSI HARGA TERHADAP KEPUTUSAN PEMBELIAN (Studi Pada Konsumen Smartphone Xiaomi di DIY)," no. 1, p. 222, 2016.

[10] W. Hendro, Chardika Respatya, Hidayat, "DIPONEGORO JOURNAL OF SOCIAL AND POLITIC Tahun 2018, Hal. 1-8 http://ejournal- s1.undip.ac.id/index.php/ Pengaruh Kualitas Produk, Harga dan Citra Merek Terhadap Keputusan Pembelian Konsumen," pp. 1-8, 2018.

[11] D. I. D. Lubis and R. Hidayat, "Pengaruh Citra Merek dan Harga terhadap Keputusan Pembelian pada Sekolah Tinggi Ilmu Manajemen Sukma Medan," J. Ilman, vol. 5, no. 1, pp. 15-24, 2017.

[12] T. Nurdin, Djuhartono, "KEPUTUSAN MEMBELI HANDPHONE MEREK SAMSUNG," vol. 11, no. 1, pp. 46-54, 2019.
[13] Kertajaya, Hermawan. 2007. Positioning, Differensiasi, dan Brand. Jakarta: Gramedia Pustaka Utama

[14] Kotler, P.(1989). Manajemen Pemasaran. Jakarta: Prenhallindo.

[15] Kotler, Philip dan Kevin Lane Keller. 2009. Manajemen Pemasaran. Jakarta: Gelora Aksara Pratama.

[16] Kotler, P., \& Keller, K. L. (2012). Marketing Management. New Jersey: Pearson Prestice Hall.

[17] Nugroho, Adi. 2002. Perilaku Konsumen. Penerbit Studia Perss. Jakarta

[18] Tjiptono. 2008. Strategi Bisnis Pemasaran. Yogyakarta: Andi. 